\title{
Marine-derived protein kinase inhibitors for neuroinflammatory diseases
}

\author{
Chong Ning ${ }^{1 \dagger}$, Hui-Min David Wang ${ }^{2,3 \dagger}$, Rong Gao ${ }^{4,5 \dagger}$, Yu-Chia Chang ${ }^{6}$, Fengqing Hu ${ }^{1}$, Xianjun Meng ${ }^{7 *}$ \\ and Shi-Ying Huang $3,8,9^{*}$
}

*Correspondence: mengxjsy@126.com; johnjohnkings@163.com; johnjohnkings@gmail.com ${ }^{\dagger}$ Chong Ning, Hui-Min David Wang and Rong Gao contributed equally to this work

${ }^{7}$ College of Food Science, Shenyang Agricultural University, Shenyang 110866 , China

${ }^{9}$ Key Laboratory of Inshore Resources Biotechnology (Quanzhou Normal University) Fujian Province University, Quanzhou 362000, China

Full list of author information is available at the end of the article

\begin{abstract}
Neuroinflammation is primarily characterized by overexpression of proinflammatory mediators produced by glial activation or immune cell infiltration. Several kinases have been shown to be critical mediators in neuroinflammation. One of the largest groups of kinases is protein kinases, which have been the second most studied group of drug targets after G-protein-coupled receptors. Thus far, most of the approved kinase inhibitor drugs are adenosine triphosphate-competitive inhibitors with various off-target liabilities because of cross-reactivities; however, marine-derived compounds provide opportunities for discovering allosteric kinase inhibitors. This review summarizes the potential of marine-derived protein kinase inhibitors in the field of neuroinflammatory diseases, such as Parkinson disease, Alzheimer disease, multiple sclerosis, and pain. The previous studies from 1990 to 2017 in this review have shown that marine-derived protein kinase inhibitors have great potential to elicit anti-neuroinflammatory or neuroprotective responses in in vitro and in vivo models of neuroinflammatory diseases. This suggests that further exploration and investigation of these marine-derived protein kinase inhibitors on neuroinflammatory diseases are warranted. Therefore, this review may inspire further discovery of new protein kinase inhibitors from a marine origin and additional neuroscience studies focusing on these valuable marine-derived protein kinase inhibitors.
\end{abstract}

Keywords: Neuroinflammation, Protein kinase inhibitors, Marine, Glia, Immune cells, In vivo

\section{Neuroinflammatory diseases}

Basically, inflammation could remove detrimental stimuli or initiate tissue healing, and therefore inflammation is a necessary and protective physiologic response to injury or infection. Similarly to inflammation, a process in response to nervous system injury is termed neuroinflammation. However, the prolonged neuroinflammation exceeds the bounds of physiological control and generates deleterious effects, including proinflammatory signaling pathways, oxidative stress, and even neuron death $[1,2]$. The types of activated cells that could cause neuroinflammation comprise the glial cells [including Schwann cells and satellite glial cells in the peripheral nervous system (PNS), and microglia, astrocytes, and oligodendrocytes in the central nervous system (CNS)], and the immune cells (including resident mast cells and macrophages as well as infiltrating neutrophils and T cells) [3]. In other words, neuroinflammation is characterized by 
immune cell infiltration or glial cell activation, with inflammatory mediator production, in the PNS and CNS [4]. There are several major neuroinflammatory diseases, such as Parkinson disease (PD) [5], Alzheimer disease (AD) [6], multiple sclerosis (MS) [7], pain [4, 8], epilepsy [9], HIV-1-associated neurocognitive disorders (HANDs) [10], Huntington disease (HD) [11], and brain ischemia [12]. The human genome has approximately 519 kinases [13]. One of the largest groups of kinases is protein kinases, which catalyze key phosphorylation pathways that regulate most aspects of cell life and have become the second most studied group of drug targets after G-protein-coupled receptors [13]. Inhibition of protein kinases are anticipated to be a source of potential therapeutic targets for human neuroinflammatory diseases, such as glycogen synthase kinase (GSK)-3 $\beta$ and cyclin dependent kinase (CDK) in PD [14] and AD [15]; c-Jun N-terminal kinase (JNK), extracellular signal-regulated kinase (ERK), and p38, subgroups of mitogen activated protein kinases (MAPKs), in PD [14], AD [15], and pain [16, 17]; FMS-like tyrosine-3 (FLT-3) and Janus kinase (JAK) in MS [18, 19]; protein kinase C (PKC) in pain [20]; tropomyosin-related kinase (Trk) in epilepsy [21]; $\mathrm{Ca}^{2+} /$ calmodulin (CaM)-dependent protein kinase (CaMK) in ischemia [22]. Most kinase-targeted drugs and related studies about potential kinase targets focus on non-CNS disorders and neurological tumors, although there are two kinase inhibitors for neuroinflammatory diseases: lithium for $A D$ by targeting GSK-3 (clinical phase II); dilmapimod (SB-681323) for neuropathic pain by targeting $\mathrm{p} 38 \alpha$ (clinical phase II) [23].

\section{Protein kinase inhibitors from a marine origin for neuroinflammatory diseases}

Almost all of the current therapeutic indications of protein kinase inhibitors are for neoplastic diseases. The treatment approval of tofacitinib for rheumatoid arthritis (in 2012) and nintedanib for idiopathic pulmonary fibrosis (in 2014), which implies that an expanded therapeutic repertoire of protein kinase inhibitors will grow in the future [24, 25]. About one-quarter of the druggable genome are kinases [26]. These findings pave a path forward for repurposing existing clinical and preclinical protein kinase inhibitors safely and efficiently as potential treatment for non-cancer diseases. On the other hand, the number of small molecule protein kinase inhibitors approved by the Food and Drug Administration (FDA) has increased at a rate of 2-4 per year, and no sign shows that this growth trend will slow down $[24,25]$. Thus far, most of the approved kinase inhibitor drugs are adenosine triphosphate-competitive inhibitors with various off-target liabilities because of cross-reactivities. However, marine-derived compounds could provide additional opportunities for discovering allosteric kinase inhibitors [13]. Twelve protein kinase inhibitors from a marine origin have entered preclinical and clinical trials: four kinase inhibitors (i.e., midostaurin, meisoindigo, lestaurtinib, enzastaurin) have entered phase III clinical studies, four kinase inhibitors (i.e., UCN-01, kahalalide F, CEP-2563, CEP-1347) have entered phase II clinical studies, one kinase inhibitor (i.e., isokahalalide F) has entered phase I clinical studies, and three kinase inhibitors (i.e., staurosporine, variolin $B$, fascaplysin) have entered preclinical investigations [13]. Whereas the therapeutic area of CEP-1347 in clinical studies was PD, the 12 other protein kinase inhibitors from a marine origin in clinical and preclinical studies were cancer [13]. Although neuroinflammatory diseases and cancer differ in several respects, they share basic mechanisms such as inflammatory processes; thus, protein kinase inhibitors may play a crucial 
Table 1 Clinical and preclinical studies on marine-derived protein kinase inhibitors for neuroinflammatory diseases

\begin{tabular}{|c|c|c|c|c|}
\hline $\begin{array}{l}\text { Status for the origi- } \\
\text { nal application }\end{array}$ & Compound & Source & Target & $\begin{array}{l}\text { Models of neuroin- } \\
\text { flammatory diseases }\end{array}$ \\
\hline Phase III for AML & $\begin{array}{l}\text { Lestaurtinib } \\
\text { (CEP-701) }\end{array}$ & $\begin{array}{l}\text { Derived from K-252a } \\
\text { from marine actino- } \\
\text { mycete }\end{array}$ & $\begin{array}{l}\text { FLT-3, JAK-2, Trk-A, } \\
\text { Trk-B, Trk-C }\end{array}$ & $\begin{array}{l}\text { MS: in vivo }[29,30] \\
\text { Epilepsy: in vivo }[31]\end{array}$ \\
\hline $\begin{array}{l}\text { Phase III for glio- } \\
\text { blastoma and } \\
\text { diffuse large B-cell } \\
\text { lymphoma }\end{array}$ & $\begin{array}{l}\text { Enzastaurin } \\
\text { (LY317615) }\end{array}$ & $\begin{array}{l}\text { Derived from stauro- } \\
\text { sporine }\end{array}$ & PKC $\beta$, GSK-3 $\beta$ & $\begin{array}{l}\text { MS: in vivo [32] } \\
\text { Pain: in vivo [33] }\end{array}$ \\
\hline Phase II for PD & $\begin{array}{l}\text { CEP-1347 } \\
\text { (KT7515) }\end{array}$ & Derived from K-252a & JNKS & $\begin{array}{l}\text { PD: patients [34]; in vivo } \\
\text { [35] } \\
\text { AD: in vitro [36, 37] } \\
\text { HANDs: in vivo [10] } \\
\text { HD: in vivo [38, 39] } \\
\text { Ischemia: in vivo [40] }\end{array}$ \\
\hline Preclinical for cancer & $\begin{array}{l}\text { Staurosporine } \\
\text { (AM-2282) }\end{array}$ & $\begin{array}{l}\text { From marine organ- } \\
\text { isms such as } \\
\text { prosobranch mol- } \\
\text { lusk, flatworm, and } \\
\text { ascidians }\end{array}$ & PKC, JAK-2, CaMKIIII & $\begin{array}{l}\text { PD: in vitro [41] } \\
\text { AD: in vitro [42] } \\
\text { Pain: in vivo [43] } \\
\text { Epilepsy: in vivo }[44] \\
\text { Ischemia: in vivo }[45,46\end{array}$ \\
\hline Preclinical for cancer & Fascaplysin & From marine sponge & CDK-4 & AD: in vitro [47] \\
\hline
\end{tabular}

$A D$ Alzheimer disease, $A M L$ acute myelogenous leukemia, $\mathrm{CaMK} \mathrm{Ca}^{2+} /$ calmodulin (CaM)-dependent protein kinase, $C D K$ cyclin dependent kinase, FLT-3 FMS-like tyrosine-3, HANDs HIV-1-associated neurocognitive disorders, HD Huntington disease, GSK glycogen synthase kinase, JAK Janus kinase, JNK c-Jun N-terminal kinase, MS multiple sclerosis, PD Parkinson disease, $P K C$ protein kinase C, Trk tropomyosin-related kinase

role in drug development in both neuroinflammatory diseases and cancer. Chronic inflammatory condition increases the risk of cancers, and potent epidemiological evidence shows that non-steroidal antiinflammatory drugs (NSAIDs), especially aspirin, are chemopreventive agents [27]. Moreover, many anti-cancer agents have been also used for treating inflammatory diseases (such as rheumatoid arthritis) [28]. Several of the aforementioned marine-derived protein kinase inhibitors have been investigated for neuroinflammatory diseases by using in vitro and in vivo systems (Table 1).

\section{Lestaurtinib}

Lestaurtinib (CEP-701; Fig. 1), a polyaromatic indolocarbazole alkaloid derived from $\mathrm{K}-252 \mathrm{a}$, is orally bioavailable in phase III clinical studies on acute myelogenous leukemia (AML) (Cephalon, Frazer, PA, USA) [48]. In 1985, Kase et al. isolated K-252a (previously named K-252; an indolocarbazole) from a culture broth of a marine actinomycete Nocardiopsis sp., Nonomuraea longicatena. Subsequently, in 1986, Kase et al. reported that K-252a is a potent inhibitor of protein kinase C and inhibits calmodulin [49]. In 1997, Kaneko et al. also reported that K-252a have broad serine/threonine and tyrosine kinase inhibitory activity, such as trk $\mathrm{A}$, protein kinase $\mathrm{C} 1$, protein kinase $\mathrm{A}$, and myosin light chain kinase [50]. Although, in relapsed/refractory (R/R) FLT3-internal tandem duplication (ITD) AML patients in 2011 [51] and during front-line consolidation in the MRC AML15 trial in 2014 [52], lestaurtinib associated with chemotherapy did not improve outcomes. In 2017, Knapper et al. reported that the addition of lestaurtinib to standard chemotherapy for newly diagnosed FLT3-mutated AML yielded no overall clinical benefit [53]. Peripheral treatment of mice with lestaurtinib $(20 \mathrm{mg} / \mathrm{kg}$, twice daily) led to a substantial improvement in locomotor function and myelin preservation 


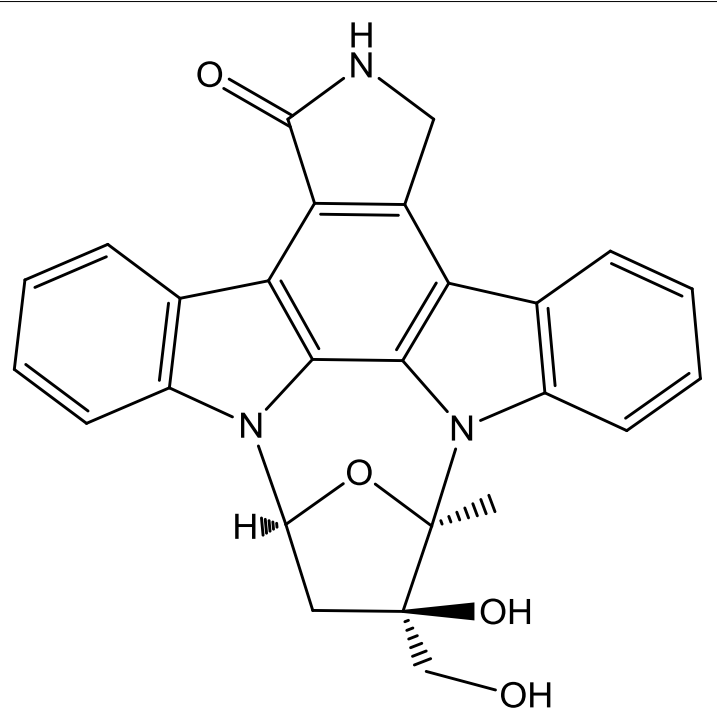

Fig. 1 Chemical structure of lestaurtinib

in the course of established experimental autoimmune encephalomyelitis (EAE) induced by myelin oligoglycoprotein $\left(\mathrm{MOG}_{35-55}\right)$, an in vivo model for MS [29]. Moreover, in EAE mice, a decrease in the number and activation states of both peripheral dendritic cells and microglia in the CNS participated in the therapeutic effects of lestaurtinib [30]. Recently, intraperitoneal (i.p.) lestaurtinib ( $3 \mathrm{mg} / \mathrm{kg}$, twice daily) has been reported to attenuate hypoxic seizure (HS)-induced seizure susceptibility in rat pups, likely through its inhibition of tropomyosin receptor kinase B [31].

\section{Enzastaurin}

Enzastaurin (LY317615; Fig. 2), an oral sugar ring modified analogue of staurosporine [13], has been examined in phase III trials for glioblastoma and diffuse large B cell lymphoma [54]. The combination of enzastaurin (twice daily oral administration at $75 \mathrm{mg}$ / $\mathrm{kg}$ ) with local irradiation attenuates osteolytic lesions and both spontaneous and movement-evoked pain behaviors in mice caused by metastatic breast cancer in bone, an in vivo model for bone cancer pain [33]. Oral treatment of mice with ongoing EAE with enzastaurin $(50 \mathrm{mg} / \mathrm{kg}$, once daily) ameliorates neuroinflammation (CNS infiltration of myelin-specific $\mathrm{T}$ cells), demyelination, axonal damage, and clinical symptoms (limb weakness or paralysis) [32].

\section{CEP-1347}

A compound CEP-1347 (KT7515; Fig. 3), originally discovered through a program researching the neurotrophic properties of semisynthetic derivatives of K-252a [55], and CEP-1347 is inhibitor of the JNK signal-transduction pathway upstream by targeting the level of the mixed lineage kinases (MLKs, including MLK1, MLK2, and MLK3) [56]. In 1999, Saporito et al. reported that subcutaneous (s.c.) administration of CEP$1347(0.3 \mathrm{mg} / \mathrm{kg} / \mathrm{d})$ attenuated 1-methyl-4-phenyl tetrahydropyridine-mediated nigrostriatal dopaminergic degeneration in a mouse model of PD [35]. In early PD patients, 


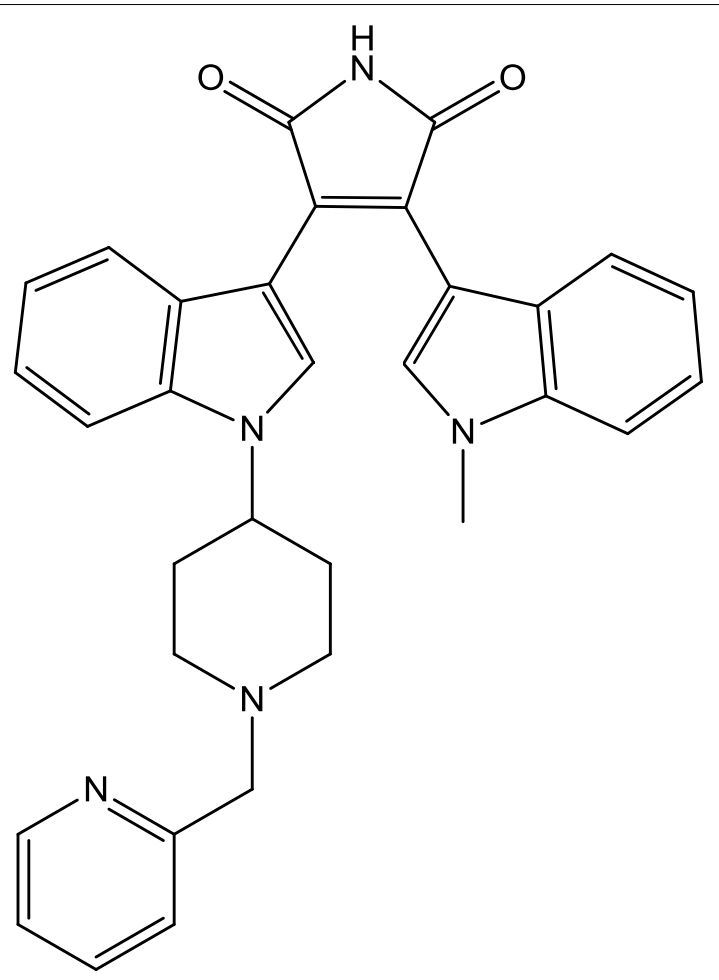

Fig. 2 Chemical structure of enzastaurin

Fig. 3 Chemical structure of CEP-1347

CEP-1347 [in dosages of $10 \mathrm{mg}$ twice daily $(n=205), 25 \mathrm{mg}$ twice daily $(n=212)$, or $50 \mathrm{mg}$ twice daily $(n=198)]$ fails to delay disability [34]. The following studies on CEP1347 for other neuroinflammatory diseases are described as follows: In an in vitro model of AD, CEP-1347 (300 nM) promotes survival and blocks activation of a Jun-N terminal kinase pathway associated with $\beta$-amyloid $(A \beta)$-induced cortical neuron apoptosis [36]. In the in vitro models of AD in another previous study, CEP-1347 (100-300 nM) 


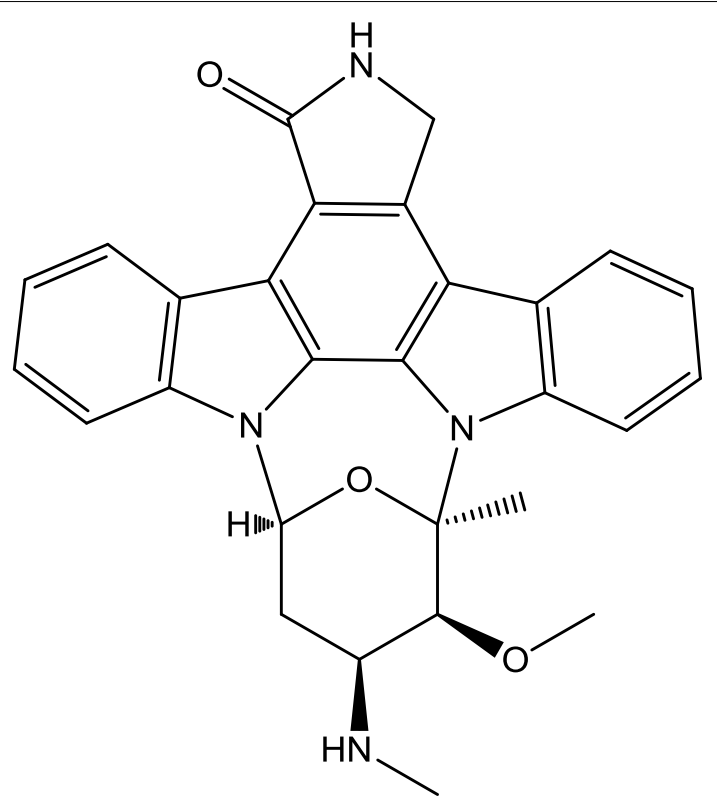

Fig. 4 Chemical structure of staurosporine

also effectively protected $\mathrm{A} \beta$-evoked-death in both PC12 cells and sympathetic neurons [37]. CEP-1347 (500 nM) inhibited mutant huntingtin-associated neurotoxicity in an in vitro HD model, and CEP-1347 (s.c.; $0.5 \mathrm{mg} / \mathrm{kg} /$ day) reduced the decline in motor performance and restored cortical brain-derived neurotrophic factor BDNF levels in R6/2 transgenic mice of the HD model [38]. Four hours after a single s.c. injection, CEP1347 ( $1 \mathrm{mg} / \mathrm{kg}$ ) was reported to increase brain-derived neurotrophic factor (BDNF) levels in blood in R6/2 mice model of HD through an increased transcription from BDNF promoter III [39]. Using in vitro models of HANDs, Eggert et al. demonstrated that CEP-1347 (220 nM) elicits an antiinflammatory phenotype in HIV-1-infected primary human monocyte-derived macrophages (MDM), thereby reducing the neurotoxicity mediated by HIV-1-infected MDM for primary murine cortical neurons [10]. In addition, the in vivo data from a mouse model for HIV-1 encephalitis showed that CEP-1347 (i.p.; $1.5 \mathrm{mg} / \mathrm{kg} /$ day) expedites neuronal survival and reduces microglial activation and dendritic damage in the brain [10]. In addition to the effects of CEP-1347 on the neurons and microglia, there is also a report about the effects of CEP-1347 on astrocytes. In the primary murine cortical astrocyte inflammation of an in vitro model, CEP-1347 is an inhibitor of astrocyte nitric oxide (NO) release (the IC50 values of CEP-1347 were $90 \pm 10 \mathrm{nM}$ ), and CEP-1347 blocks the expression of inducible NO synthase (iNOS) and cyclooxygenase-2 (COX-2) at the transcriptional level [57]. In a neonatal rat model of hypoxia-ischemia, s.c. CEP-1347 (1 mg/kg, once daily) has protective effects, which is related to reduced apoptosis [40].

\section{Staurosporine}

In 1977, during a search for new alkaloids present in actinomycetes, Omura et al. isolated AM-2282 (renamed staurosporine; Fig. 4) from Streptomyces staurosporeus [58]. Staurosporine has been isolated from some marine organisms such as the prosobranch 


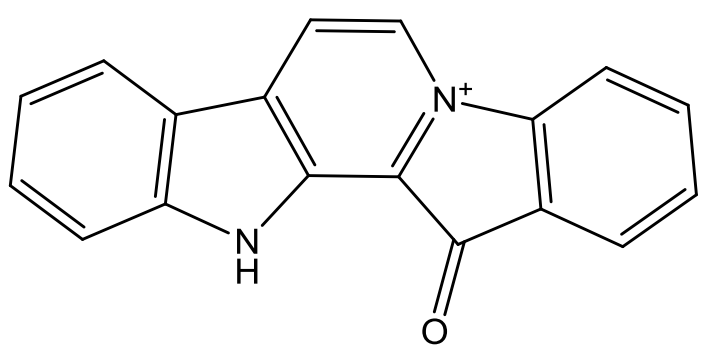

Fig. 5 Chemical structure of fascaplysin

mollusk, flatworm, and ascidians [59]. In 1990, Hara et al. showed that topical injection into the $\mathrm{CA}_{1}$ subfield of the hippocampus of staurosporine (10 $\mathrm{ng}$ ) administered $30 \mathrm{~min}$ before ischemia prevented neuronal death in gerbil and rat ischemia models [45]. Moreover, Ohno et al. indicated that staurosporine administered (i.p.; $0.03 \mathrm{mg} / \mathrm{kg}$ ) immediately after blood flow reperfusion significantly reduced the impairment of working memory in rats following transient forebrain ischemia [46]. Both seizure-induced damage to hippocampal neurons and associated visuospatial memory deficits were significantly reduced in rats administered staurosporine (s.c. injections of $4 \mu \mathrm{g} / \mathrm{kg} / \mathrm{day}$ ) prior to kainic acid administration [44]. In addition to these in vivo studies, in in vitro models of $\mathrm{AD}$, staurosporine $(100 \mathrm{pM})$ can protect cultured rat hippocampal neurons against $\mathrm{A} \beta$ toxicity or iron-induced injury [42]. Moreover, intradermal injection of staurosporine (500 ng) reduced the mechanical hyperalgesia in streptozotocin-induced diabetic rats but did not alter thresholds in normal rats [43]. On the other hand, one of the pathological characteristics in the early stages of PD is axonal degeneration of dopaminergic neurons, and therefore promotion of axonal outgrowth of the remaining dopaminergic neurons results in the recovery of the nigrostriatal pathway [41]. Through AMP-activated protein kinase (AMPK)/mammalian target of rapamycin (mTOR) signaling pathway, staurosporine $(10 \mathrm{nM})$ induces dopaminergic neurite outgrowth in mesencephalic primary cultures [41]. However, staurosporine is excessively toxic for clinical development [13]. Through improved toxicity profiles, several staurosporine analogues have advanced to various stages of clinical development, such as midostaurin (clinical phase III), lestaurtinib (clinical phase III), enzastaurin (clinical phase III), edotecarin (not an inhibitor of protein kinases; clinical phase III), becatecarin (not inhibitor of protein kinases; clinical phase III), UCN-01 (clinical phase II), CEP-2563 (clinical phase II), and CEP-1347 (clinical phase II) [13].

\section{Fascaplysin}

Fascaplysin (Fig. 5), a bis-indole alkaloid, was isolated from a marine sponge Fascaplysinopsis Bergquist sp. [60]. Fascaplysin is a specific kinase inhibitor for CDK 4 [61]. In 2013, Sanphui et al. demonstrated that fascaplysin chloride $(0.4 \mu \mathrm{M})$ protected rat neuronal pheochromocytoma 12 cells from death induced by nerve growth factor deprivation, an in vitro model of $\mathrm{AD}$ [47]. 


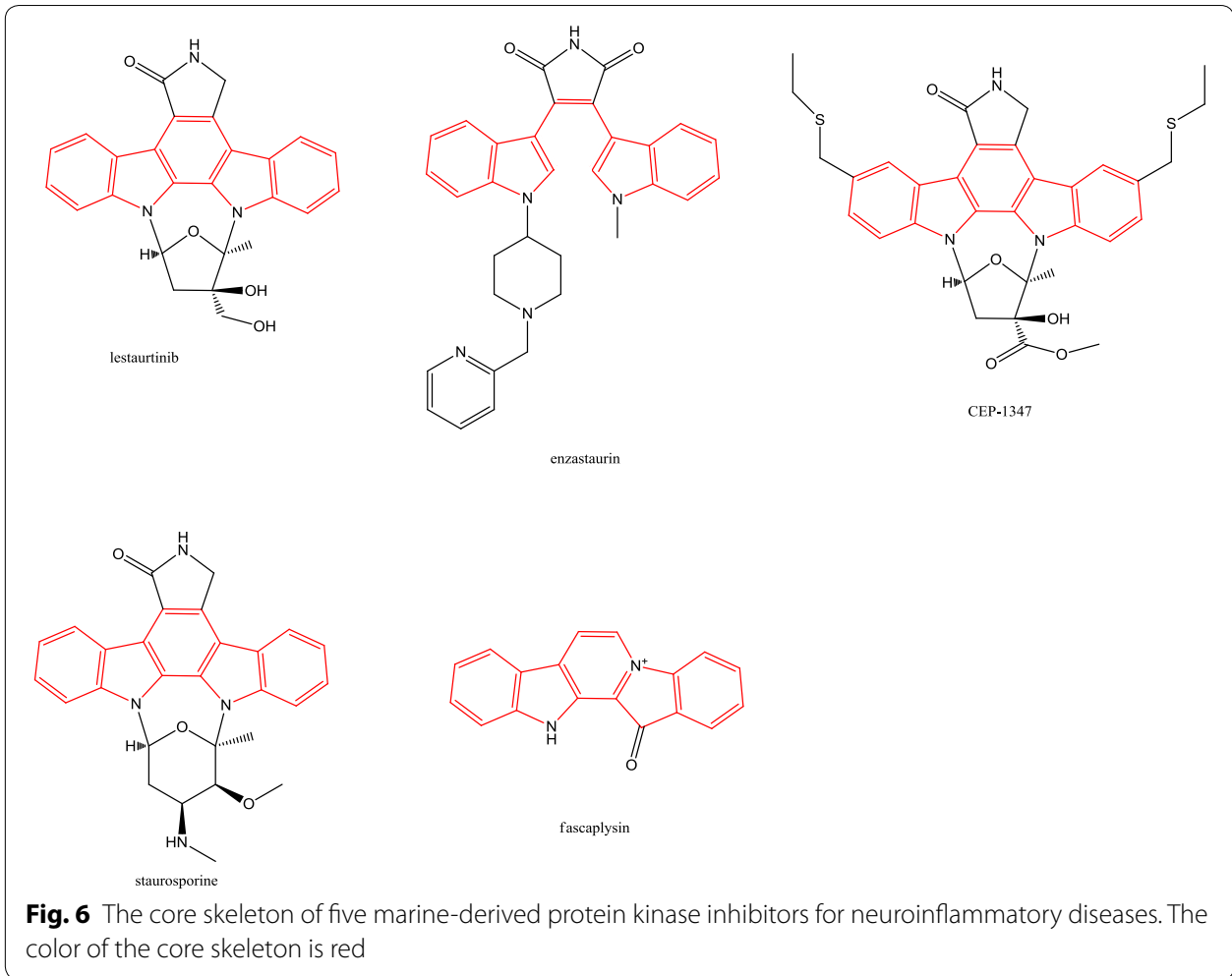

\section{Future advantages and challenges for marine-derived protein kinase inhibitors}

Figure 6 shows the core skeleton of five marine-derived protein kinase inhibitors for neuroinflammatory diseases. It would further be expected that the analogues of 11,12-dihydroindolo[2,3-a] carbazole and $N$-substituted $\beta$-carboline class of fascaplysininspired compounds might have great potential to elicit antineuroinflammatory or neuroprotective responses in models of neuroinflammatory diseases. The CDK inhibitor (including fascaplysin) could be potential antiinflammatory and pro-resolution agents, such as R-roscovitine have shown potential antiinflammatory effects that could influence the resolution of inflammation [62]. In 1996, Smith-Swintosky et al. considered that low-molecular-weight lipophilic alkaloids (K252 compounds and staurosporine) can pass the blood-brain barrier (BBB) [44], and this hypothesis is supported by the aforementioned studies conducted in vivo. The ability of these marine-derived protein kinase inhibitors to pass the BBB is an advantage for future clinical uses for both neuroinflammatory diseases and tumors in the CNS. Specifically, at present, the therapeutic area of these protein kinase inhibitors from a marine origin in clinical and preclinical studies is peripheral cancer. The topic of these marine-derived protein kinase inhibitors on CNS tumors might be another worthwhile direction for further research. In addition, there were several patents about application of these marine-derived protein kinase inhibitors or their derivatives, including lestaurtinib for the treatment of neurodegenerative diseases [63] and the treatment or prevention of pain disorders [64], enzastaurin for the treatment of neurological diseases [65], and bis-N-substituted derivatives of staurosporine for the treatment of neurological disorders [66, 67]. Recent projects have 
Table 2 The marine-derived extracts or compounds with in vitro anti-neuroinflammatory activity

\begin{tabular}{|c|c|c|c|}
\hline Extracts or compounds & Marine source & Therapeutic area & Possible molecular pathway \\
\hline Methanol extracts & $\begin{array}{l}\text { Marine green algae } \\
\text { Ulva conglobata }\end{array}$ & Neuroinflammation & $\begin{array}{l}\text { Inhibition of iNOS and COX-2 } \\
\text { [77] }\end{array}$ \\
\hline $\begin{array}{l}\text { Alginate-derived oligosac- } \\
\text { charide }\end{array}$ & Various brown algae & $A D$ & $\begin{array}{l}\text { Inactivation the TLR4-NF-KB } \\
\text { signaling pathway [78] }\end{array}$ \\
\hline Dieckol & $\begin{array}{l}\text { Brown algae } \\
\text { Ecklonia cava }\end{array}$ & Neuroinflammation & $\begin{array}{l}\text { Downregulation of ERK, Akt } \\
\text { and NADPH oxidase-medi- } \\
\text { ated pathways [79] }\end{array}$ \\
\hline Floridoside & $\begin{array}{l}\text { Red algae } \\
\text { Laurencia undulata }\end{array}$ & Neuroinflammation & Inhibition of p38 and ERK [80] \\
\hline Phlorofucofuroeckol B & $\begin{array}{l}\text { Brown algae } \\
\text { Ecklonia stolonifera }\end{array}$ & Neuroinflammation & $\begin{array}{l}\text { Inhibition of IkB-alpha/NF-kB } \\
\text { and Akt/ERKJJNK pathways } \\
\text { [81] }\end{array}$ \\
\hline Aurantiamide acetate & $\begin{array}{l}\text { Marine fungus } \\
\text { Aspergillus sp. SF-5921 }\end{array}$ & Neuroinflammation & $\begin{array}{l}\text { Inhibition of NF-KB, JNK, and } \\
\text { p38 [82] }\end{array}$ \\
\hline Citreohybridonol & $\begin{array}{l}\text { Marine fungus } \\
\text { Toxicocladosporium sp. } \\
\text { SF-5699 }\end{array}$ & Neuroinflammation & $\begin{array}{l}\text { Inhibitory effect on the NF-KB } \\
\text { and p38 pathways [83] }\end{array}$ \\
\hline Sinuleptolide & $\begin{array}{l}\text { Soft coral } \\
\text { Sinularia kavarattiensis }\end{array}$ & Neuroinflammation & $\begin{array}{l}\text { Inhibition of IL-1 } \beta \text {, IL-6, IL-8, } \\
\text { |L-18, and TNF-a [84] }\end{array}$ \\
\hline
\end{tabular}

$A D$ Alzheimer disease, $C O X-2$ cyclooxygenase-2, ERK extracellular signal-regulated kinase, IKB inhibitor of NF- $\mathrm{KB}$, IL interleukin, iNOS inducible nitric oxide synthase, JNK c-Jun $\mathrm{N}$-terminal kinase, NADPH nicotinamide adenine dinuclelotide phosphate, NF-KB nuclear factor KB, TLR4 toll-like receptor 4, TNF- $a$ tumor necrosis factor-a

begun to identify non-kinase targets for kinase inhibitors [68], which could be the third possible future research directions of these marine-derived protein kinase inhibitors. On the other hand, because the problem of a continuous supply of natural marine products is a major challenge in conducting preclinical and clinical trials on marine drugs [69, 70], few marine-derived protein kinase inhibitors for neuroinflammatory diseases have been approved by the FDA and few studies have been conducted in vivo [71]. To overcome the supply problem of natural marine products, several strategies, such as (1) total chemical synthesis (2) semisynthetic production, (3) fermentation, (4) sampling strategies, (5) nanoscale NMR for structure elucidation, and (6) biotechnology [69, 70, 72], are being developed. Another major challenge for natural marine products is target identification [70]. Although the molecular target-based approach (i.e., reverse pharmacology) for drug discovery has been widely adopted in the past 25 years, phenotypicbased screening strategies (i.e., forward pharmacology) have become the foundation of pharmaceutical drug discovery [73]. Based on phenotypic-based screening strategies, several marine-derived compounds might reduce in vitro (Table 2) or in vivo (Table 3) neuroinflammatory processes. Grosso et al. have outlined bioactive marine compounds with anti-neuroinflammatory activity [71]. Barbosa et al. also have summarized bioactive compounds from macroalgae for several neuroinflammatory diseases [74]. Although target identification for phenotypic-based screening strategies is complex and time consuming [73], further target identification of these marine-derived compounds is warranted. The third major challenge for natural marine products, particularly for marine-derived protein kinase inhibitors, is identifying new drug targets from biomedical research [73]. After reviewing 989 FDA-approved drugs with human targets from the DrugBank database, Rask-Andersen et al. indicated only 435 effective drug targets 
Table 3 The marine-derived extracts or compounds with in vivo anti-neuroinflammatory activity

\begin{tabular}{|c|c|c|c|}
\hline Extracts or compounds & Marine source & Therapeutic area & Possible molecular pathway \\
\hline Ethanol extract & $\begin{array}{l}\text { Marine microalgae } \\
\text { Nannochloropsis oceanica }\end{array}$ & $A D$ & $\begin{array}{l}\text { Down-regulation of APP and } \\
\text { BACE1 expression [85] }\end{array}$ \\
\hline MS14 & $\begin{array}{l}\text { MS14 is a natural herbal- } \\
\text { marine drug }\end{array}$ & MS & $\begin{array}{l}\text { Inhibition of spinal LCN2 [86, } \\
\text { 87] } \\
\text { (MS14 consists of 90\% Penaeus } \\
\text { latisculatus (king prawn), 5\% } \\
\text { Apium graveolens (celery), } \\
\text { and 5\% Hypericum perfora- } \\
\text { tum L. (St John's wort).) }\end{array}$ \\
\hline 11-Dehydrosinulariolide & $\begin{array}{l}\text { Soft coral } \\
\text { Sinularia flexibilis }\end{array}$ & PD & $\begin{array}{l}\text { In vitro: inhibition of NF-kB [88] } \\
\text { In vivo: increase of DJ-1 } \\
\text { expression [89] }\end{array}$ \\
\hline $\begin{array}{l}\text { Dihydroaustrasulfone } \\
\text { alcohol }\end{array}$ & $\begin{array}{l}\text { The synthetic precursor of } \\
\text { austrasulfone from the } \\
\text { Soft coral } \\
\text { Cladiella australis }\end{array}$ & MS and pain & $\begin{array}{l}\text { Inhibition of iNOS and COX-2 } \\
\text { based on in vitro data [90] }\end{array}$ \\
\hline Capnellene & $\begin{array}{l}\text { Soft coral } \\
\text { Capnella imbricate }\end{array}$ & Pain & Inhibition of spinal COX-2 [91] \\
\hline Lemnalol & $\begin{array}{l}\text { Soft coral } \\
\text { Lemnalia cervicorni }\end{array}$ & Pain & Inhibition of spinal TNF-a [92] \\
\hline Flexibilide & $\begin{array}{l}\text { Soft coral } \\
\text { Sinularia flexibilis }\end{array}$ & Pain & Inhibition of spinal iNOS [93] \\
\hline $\mathrm{DHA}$ & Fish & Pain & Inhibition of spinal p38 [94] \\
\hline Xyloketal B & $\begin{array}{l}\text { Marine fungus Xylaria sp. } \\
\text { (strain no. 2508) }\end{array}$ & Ischemia & $\begin{array}{l}\text { Inhibition of brain caspase-3 } \\
\text { and Bax [95] }\end{array}$ \\
\hline Polyphenols & $\begin{array}{l}\text { Brown algae } \\
\text { Ecklonia cava }\end{array}$ & Ischemia & $\begin{array}{l}\text { Inhibition of cytosolic calcium } \\
\text { based on in vitro data [96] }\end{array}$ \\
\hline
\end{tabular}

$A D$ Alzheimer disease, $B A C E 1$ beta-secretase 1, COX-2 cyclooxygenase-2, DHA docosahexaenoic acid, iNOS inducible nitric oxide synthase, LCN2 Lipocaline2, MS multiple sclerosis, NF-KB nuclear factor KB, PD Parkinson disease, $T N F-a$ tumor necrosis factor-a

[75], although 30,000 human genes create approximately 90,000 proteins [76]. Zheng et al. asserted that failures in discovery and validation of new targets have partially contributed to the substantial decrease in the quantity of newly approved drugs in the past decade [73].

\section{Summary}

The studies from 1990 to 2014 in this review have demonstrated that marine-derived protein kinase inhibitors (i.e., lestaurtinib, enzastaurin, CEP-1347, staurosporine, and fascaplysin) have great potential to elicit anti-neuroinflammatory or neuroprotective responses in in vitro and in vivo models of human neuroinflammatory diseases. This suggests that further exploration and investigation of these marine-derived protein kinase inhibitors on neuroinflammatory diseases are warranted. Therefore, the present review may inspire further discovery of new protein kinase inhibitors from a marine origin and neuroscience researchers to perform additional studies focusing on these valuable marine-derived protein kinase inhibitors.

Authors' contributions

Conceived and designed the manuscript: $\mathrm{CN}, \mathrm{H}-\mathrm{MW}, \mathrm{RG}, \mathrm{XM}, \mathrm{S}-\mathrm{YH}$; contributed to tables and figures: Y-CC, FH, S-YH; wrote the paper: $\mathrm{CN}, \mathrm{H}-\mathrm{MW}, \mathrm{RG}, \mathrm{XM}, \mathrm{S}-\mathrm{YH}$. All authors read and approved the final manuscript. 


\begin{abstract}
Author details
${ }^{1}$ College of Light Industry, Liaoning University, Shenyang 110036, China. ${ }^{2}$ Graduate Institute of Biomedical Engineering, National Chung Hsing University, Taichung 40227, Taiwan. ${ }^{3}$ College of Oceanology and Food Science, Quanzhou Normal University, Quanzhou 362000, China. ${ }^{4}$ Yangtze Delta Region Institute of Tsinghua University, Zhejiang 314006 , China. ${ }^{5}$ Jiaxing Deqin Biotechnology Co., Ltd, Zhejiang 314006, China. ${ }^{6}$ Greenhouse Systems Technology Center, Central Region Campus, Industrial Technology Research Institute, Nantou 540, Taiwan. ${ }^{7}$ College of Food Science, Shenyang Agricultural University, Shenyang 110866, China. ${ }^{8}$ Fujian Province Key Laboratory for the Development of Bioactive Material from Marine Algae, Quanzhou 362000, China. ${ }^{9}$ Key Laboratory of Inshore Resources Biotechnology (Quanzhou Normal University) Fujian Province University, Quanzhou 362000, China.
\end{abstract}

\title{
Acknowledgements
}

This work was supported, in part, by Grants from Quanzhou Normal University (3001-G16037), Shenyang City Science and Technology Projects (17-136-8-00), and Foundation of Liaoning Educational Committee (LQN201713).

\section{Competing interests}

The authors declare that they have no competing interests.

\section{Ethics approval and consent to participate}

Not applicable.

\section{Publisher's Note}

Springer Nature remains neutral with regard to jurisdictional claims in published maps and institutional affiliations.

Received: 16 December 2017 Accepted: 17 April 2018

Published online: 24 April 2018

\section{References}

1. Dong H, Zhang X, Qian Y. Mast cells and neuroinflammation. Med Sci Monit Basic Res. 2014;20:200-6.

2. DiSabato DJ, Quan N, Godbout JP. Neuroinflammation: the devil is in the details. J Neurochem. 2016;139(Suppl 2):136-53.

3. Huh Y, Ji RR, Chen G. Neuroinflammation, bone marrow stem cells, and chronic pain. Front Immunol. 2017;8:1014.

4. Ji RR, Xu ZZ, Gao YJ. Emerging targets in neuroinflammation-driven chronic pain. Nat Rev Drug Discov. 2014;13:533-48.

5. Hirsch EC, Vyas S, Hunot S. Neuroinflammation in Parkinson's disease. Parkinsonism Relat Disord. 2012;18(Suppl 1):S210-2.

6. Rai S, Kamat PK, Nath C, Shukla R. Glial activation and synaptic neurotoxicity in Alzheimer's disease: a focus on neuroinflammation. Pharmacologia. 2014;5:286-97.

7. Grigoriadis N, Grigoriadis S, Polyzoidou E, Milonas I, Karussis D. Neuroinflammation in multiple sclerosis: evidence for autoimmune dysregulation, not simple autoimmune reaction. Clin Neurol Neurosurg. 2006;108:241-4.

8. Ellis A, Bennett DLH. Neuroinflammation and the generation of neuropathic pain. Br J Anaesth. 2013;111:26-37.

9. Foresti ML, Arisi GM, Shapiro LA. Role of glia in epilepsy-associated neuropathology, neuroinflammation and neurogenesis. Brain Res Rev. 2011;66:115-22.

10. Eggert D, Dash PK, Gorantla S, Dou H, Schifitto G, Maggirwar SB, et al. Neuroprotective activities of CEP-1347 in models of neuroAIDS. J Immunol. 2010;184:746-56.

11. Moller T. Neuroinflammation in Huntington's disease. J Neural Transm. 2010;117:1001-8.

12. Pedata F, Pugliese AM, Coppi E, Dettori I, Maraula G, Cellai L, et al. Adenosine A2A receptors modulate acute injury and neuroinflammation in brain ischemia. Mediators Inflamm. 2014;2014:805198.

13. Bharate SB, Sawant SD, Singh PP, Vishwakarma RA. Kinase inhibitors of marine origin. Chem Rev. 2013;113:6761-815.

14. Wang G, Pan J, Chen SD. Kinases and kinase signaling pathways: potential therapeutic targets in Parkinson's disease. Prog Neurobiol. 2012;98:207-21.

15. Tell V, Hilgeroth A. Recent developments of protein kinase inhibitors as potential AD therapeutics. Front Cell Neurosci. 2013;7:189.

16. Crown ED. The role of mitogen activated protein kinase signaling in microglia and neurons in the initiation and maintenance of chronic pain. Exp Neurol. 2012;234:330-9.

17. Chen NF, Chen WF, Sung CS, Lu CH, Chen CL, Hung HC, et al. Contributions of $\mathrm{p} 38$ and ERK to the antinociceptive effects of TGF-beta1 in chronic constriction injury-induced neuropathic rats. J Headache Pain. 2016;17:72.

18. Liu Y, Holdbrooks AT, De Sarno P, Rowse AL, Yanagisawa LL, McFarland BC, et al. Therapeutic efficacy of suppressing the JAK/STAT pathway in multiple models of experimental autoimmune encephalomyelitis. I Immunol. 2014;192:59-72.

19. Mirshafiey A, Ghalamfarsa G, Asghari B, Azizi G. Receptor tyrosine kinase and tyrosine kinase inhibitors: new hope for success in multiple sclerosis therapy. Innov Clin Neurosci. 2014;11:23-36.

20. Kamei J, Mizoguchi H, Narita M, Tseng LF. Therapeutic potential of PKC inhibitors in painful diabetic neuropathy. Expert Opin Investig Drugs. 2001;10:1653-64.

21. Liu G, Gu B, He XP, Joshi RB, Wackerle HD, Rodriguiz RM, et al. Transient inhibition of TrkB kinase after status epilepticus prevents development of temporal lobe epilepsy. Neuron. 2013;79:31-8.

22. Coultrap SJ, Vest RS, Ashpole NM, Hudmon A, Bayer KU. CaMKIl in cerebral ischemia. Acta Pharmacol Sin. 2011;32:861-72 
23. Chico LK, Van Eldik LJ, Watterson DM. Targeting protein kinases in central nervous system disorders. Nat Rev Drug Discov. 2009;8:892-909

24. Roskoski R Jr. Classification of small molecule protein kinase inhibitors based upon the structures of their drugenzyme complexes. Pharmacol Res. 2016;103:26-48.

25. Roskoski R Jr. A historical overview of protein kinases and their targeted small molecule inhibitors. Pharmacol Res. 2015;100:1-23.

26. Hopkins AL, Groom CR. The druggable genome. Nat Rev Drug Discov. 2002;1:727-30

27. Crusz SM, Balkwill FR. Inflammation and cancer: advances and new agents. Nat Rev Clin Oncol. 2015;12:584-96.

28. Rayburn ER, Ezell SJ, Zhang R. Anti-inflammatory agents for cancer therapy. Mol Cell Pharmacol. 2009;1:29-43.

29. Whartenby KA, Calabresi PA, McCadden E, Nguyen B, Kardian D, Wang T, et al. Inhibition of FLT3 signaling targets DCs to ameliorate autoimmune disease. Proc Natl Acad Sci USA. 2005;102:16741-6.

30. Skarica M, Wang T, McCadden E, Kardian D, Calabresi PA, Small D, et al. Signal transduction inhibition of APCs diminishes Th17 and Th1 responses in experimental autoimmune encephalomyelitis. J Immunol. 2009;182:4192-9.

31. Obeid M, Rosenberg EC, Klein PM, Jensen FE. Lestaurtinib (CEP-701) attenuates "second hit" kainic acid-induced seizures following early life hypoxic seizures. Epilepsy Res. 2014;108:806-10.

32. Lanz TV, Becker S, Osswald M, Bittner S, Schuhmann MK, Opitz CA, et al. Protein kinase Cbeta as a therapeutic target stabilizing blood-brain barrier disruption in experimental autoimmune encephalomyelitis. Proc Natl Acad Sci USA. 2013:110:14735-40.

33. Dudek AZ, Zwolak P, Jasinski P, Terai K, Gallus NJ, Ericson ME, et al. Protein kinase C-beta inhibitor enzastaurin (LY317615.HCl) enhances radiation control of murine breast cancer in an orthotopic model of bone metastasis. Invest New Drugs. 2008;26:13-24.

34. Parkinson Study Group PI. Mixed lineage kinase inhibitor CEP-1347 fails to delay disability in early Parkinson disease. Neurology. 2007;69:1480-90.

35. Saporito MS, Brown EM, Miller MS, Carswell S. CEP-1347/KT-7515, an inhibitor of c-jun N-terminal kinase activation attenuates the 1-methyl-4-phenyl tetrahydropyridine-mediated loss of nigrostriatal dopaminergic neurons in vivo. J Pharmacol Exp Ther. 1999;288:421-7.

36. Bozyczko-Coyne D, O'Kane TM, Wu ZL, Dobrzanski P, Murthy S, Vaught JL, et al. CEP-1347/KT-7515, an inhibitor of SAPK/JNK pathway activation, promotes survival and blocks multiple events associated with Abeta-induced cortical neuron apoptosis. J Neurochem. 2001;77:849-63.

37. Troy CM, Rabacchi SA, Xu Z, Maroney AC, Connors TJ, Shelanski ML, et al. beta-Amyloid-induced neuronal apoptosis requires c-Jun N-terminal kinase activation. J Neurochem. 2001;77:157-64.

38. Apostol BL, Simmons DA, Zuccato C, Illes K, Pallos J, Casale M, et al. CEP-1347 reduces mutant huntingtin-associated neurotoxicity and restores BDNF levels in R6/2 mice. Mol Cell Neurosci. 2008:39:8-20.

39. Conforti P, Ramos C, Apostol BL, Simmons DA, Nguyen HP, Riess O, et al. Blood level of brain-derived neurotrophic factor mRNA is progressively reduced in rodent models of Huntington's disease: restoration by the neuroprotective compound CEP-1347. Mol Cell Neurosci. 2008;39:1-7.

40. Carlsson Y, Leverin AL, Hedtjarn M, Wang X, Mallard C, Hagberg H. Role of mixed lineage kinase inhibition in neonatal hypoxia-ischemia. Dev Neurosci. 2009;31:420-6.

41. Wakita S, Izumi Y, Nakai T, Adachi K, Takada-Takatori Y, Kume T, et al. Staurosporine induces dopaminergic neurite outgrowth through AMP-activated protein kinase/mammalian target of rapamycin signaling pathway. Neuropharmacology. 2014;77:39-48.

42. Goodman Y, Mattson MP. Staurosporine and K-252 compounds protect hippocampal neurons against amyloid $\beta$-peptide toxicity and oxidative injury. Brain Res. 1994;650:170-4.

43. Ahlgren SC, Levine JD. Protein kinase C inhibitors decrease hyperalgesia and C-fiber hyperexcitability in the streptozotocin-diabetic rat. J Neurophysiol. 1994;72:684-92.

44. Smith-Swintosky VL, Kraemer PJ, Bruce AJ, McCants N, Maki A, Brown RW, et al. Bacterial alkaloids mitigate seizureinduced hippocampal damage and spatial memory deficits. Exp Neurol. 1996;141:287-96.

45. Hara H, Onodera H, Yoshidomi M, Matsuda Y, Kogure K. Staurosporine, a novel protein kinase C inhibitor, prevents postischemic neuronal damage in the gerbil and rat. J Cereb Blood Flow Metab. 1990;10:646-53.

46. Ohno M, Yamamoto T, Watanabe S. Effect of staurosporine, a protein kinase $\mathrm{C}$ inhibitor, on impairment of working memory in rats exposed to cerebral ischemia. Eur J Pharmacol. 1991;204:113-6.

47. Sanphui P, Pramanik SK, Chatterjee N, Moorthi P, Banerji B, Biswas SC. Efficacy of cyclin dependent kinase 4 inhibitors as potent neuroprotective agents against insults relevant to Alzheimer's disease. PLoS ONE. 2013;8:e78842.

48. Shabbir M, Stuart R. Lestaurtinib, a multitargeted tyrosine kinase inhibitor: from bench to bedside. Expert Opin Investig Drugs. 2010;19:427-36.

49. Kase H, Iwahashi K, Matsuda Y. K-252a, a potent inhibitor of protein kinase C from microbial origin. J Antibiot (Tokyo). 1986:39:1059-65.

50. Kaneko M, Saito Y, Saito H, Matsumoto T, Matsuda Y, Vaught JL, et al. Neurotrophic 3,9-bis[(alkylthio)methyl]-andbis(alkoxymethyl)-K-252a derivatives. J Med Chem. 1997;40:1863-9.

51. Levis M, Ravandi F, Wang ES, Baer MR, Perl A, Coutre S, et al. Results from a randomized trial of salvage chemotherapy followed by lestaurtinib for patients with FLT3 mutant AML in first relapse. Blood. 2011;117:3294-301.

52. Knapper S, Hills RK, Cavenagh JD, Kjeldsen L, Hunter AE, Clark RE, et al. A randomised comparison of the sequential addition of the FLT3 Inhibitor lestaurtinib (CEP701) to standard first line chemotherapy for FLT3-mutated acute myeloid leukemia: the UK experience. Blood. 2014;124:3736.

53. Knapper S, Russell N, Gilkes A, Hills RK, Gale RE, Cavenagh JD, et al. A randomized assessment of adding the kinase inhibitor lestaurtinib to first-line chemotherapy for FLT3-mutated AML. Blood. 2017:129:1143-54

54. Vergote I. Novel therapies, including enzastaurin, in the treatment of ovarian cancer. Expert Opin Investig Drugs. 2014:23:579-98.

55. Sweeney ZK, Lewcock JW. ACS chemical neuroscience spotlight on CEP-1347. ACS Chem Neurosci. 2011;2:3-4.

56. Maroney AC, Finn JP, Connors TJ, Durkin JT, Angeles T, Gessner G, et al. Cep-1347 (KT7515), a semisynthetic inhibitor of the mixed lineage kinase family. J Biol Chem. 2001;276:25302-8. 
57. Falsig J, Porzgen P, Lotharius J, Leist M. Specific modulation of astrocyte inflammation by inhibition of mixed lineage kinases with CEP-1347. J Immunol. 2004;173:2762-70.

58. Park BS, Abdel-Azeem AZ, Al-Sanea MM, Yoo KH, Tae JS, Lee SH. Staurosporine analogues from microbial and synthetic sources and their biological activities. Curr Med Chem. 2013;20:3872-902.

59. Schupp P, Steube K, Meyer C, Proksch P. Anti-proliferative effects of new staurosporine derivatives isolated from a marine ascidian and its predatory flatworm. Cancer Lett. 2001;174:165-72.

60. Bharate SB, Manda S, Mupparapu N, Battini N, Vishwakarma RA. Chemistry and biology of fascaplysin, a potent marine-derived CDK-4 inhibitor. Mini Rev Med Chem. 2012;12:650-64.

61. Shafiq Ml, Steinbrecher T, Schmid R. Fascaplysin as a specific inhibitor for CDK4: insights from molecular modelling PLOS ONE. 2012;7:e42612.

62. Leitch AE, Haslett C, Rossi AG. Cyclin-dependent kinase inhibitor drugs as potential novel anti-inflammatory and pro-resolution agents. Br J Pharmacol. 2009;158:1004-16.

63. Zack DJ, Yang Z, Berlinicke C, Quigley H. Compositions and methods for treatment of neurodegenerative disease. US8993615B2. 2015

64. Valmier J. FLT3 receptor antagonists for the treatment or the prevention of pain disorders. US9109227B2. 2015.

65. Haggarty SJ, Fass D, Pan J, Ketterman J, Holson E, Petryshen TL, et al. Uses of chemicals to modulate gsk-3 signaling for treatment of bipolar disorder and other brain disorders. US9265764B2. 2016.

66. Lewis ME, Kauer JC, Neff N, Roberts-Lewis J, Murakata C, Saito H, et al. Selected protein kinase inhibitors for the treatment of neurological disorders. US5461146A. 1995.

67. Lewis ME, Kauer JC, Neff N, Roberts-Lewis J, Murakata C, Saito H, et al. K-252a derivatives for treatment of neurological disorders. US5621100A. 1997.

68. Munoz L. Non-kinase targets of protein kinase inhibitors. Nat Rev Drug Discov. 2017:16:424-40.

69. Liu Y. Renaissance of marine natural product drug discovery and development. J Mar Sci Res Dev. 2012;02:e106.

70. Montaser R, Luesch H. Marine natural products: a new wave of drugs? Future Med Chem. 2011;3:1475-89.

71. Grosso C, Valentao P, Ferreres F, Andrade PB. Bioactive marine drugs and marine biomaterials for brain diseases. Mar Drugs. 2014;12:2539-89.

72. Burgess JG. New and emerging analytical techniques for marine biotechnology. Curr Opin Biotechnol. 2012;23:29-33.

73. Zheng W, Thorne N, McKew JC. Phenotypic screens as a renewed approach for drug discovery. Drug Discov Today. 2013;18:1067-73.

74. Barbosa M, Valentao $\mathrm{P}$, Andrade PB. Bioactive compounds from macroalgae in the new millennium: implications for neurodegenerative diseases. Mar Drugs. 2014;12:4934-72.

75. Rask-Andersen M, Almen MS, Schioth HB. Trends in the exploitation of novel drug targets. Nat Rev Drug Discov. 2011;10:579-90

76. Stamm S. Signals and their transduction pathways regulating alternative splicing: a new dimension of the human genome. Hum Mol Genet. 2002;11:2409-16.

77. Jin DQ, Lim CS, Sung JY, Choi HG, Ha I, Han JS. Ulva conglobata, a marine algae, has neuroprotective and anti-inflammatory effects in murine hippocampal and microglial cells. Neurosci Lett. 2006;402:154-8.

78. Zhou R, Shi XY, Bi DC, Fang WS, Wei GB, Xu X. Alginate-derived oligosaccharide inhibits neuroinflammation and promotes microglial phagocytosis of beta-amyloid. Mar Drugs. 2015;13:5828-46.

79. Cui Y, Park JY, Wu J, Lee JH, Yang YS, Kang MS, et al. Dieckol attenuates microglia-mediated neuronal cell death via ERK, Akt and NADPH oxidase-mediated pathways. Korean J Physiol Pharmacol. 2015;19:219-28.

80. Kim M, Li YX, Dewapriya P, Ryu B, Kim SK. Floridoside suppresses pro-inflammatory responses by blocking MAPK signaling in activated microglia. BMB Rep. 2013;46:398-403.

81. Yu DK, Lee B, Kwon M, Yoon N, Shin T, Kim NG, et al. Phlorofucofuroeckol B suppresses inflammatory responses by down-regulating nuclear factor kappaB activation via Akt, ERK, and JNK in LPS-stimulated microglial cells. Int Immunopharmacol. 2015;28:1068-75.

82. Yoon CS, Kim DC, Lee DS, Kim KS, Ko W, Sohn JH, et al. Anti-neuroinflammatory effect of aurantiamide acetate from the marine fungus Aspergillus sp. SF-5921: inhibition of NF-kappaB and MAPK pathways in lipopolysaccharideinduced mouse BV2 microglial cells. Int Immunopharmacol. 2014;23:568-74.

83. Cho KH, Kim DC, Yoon CS, Ko WM, Lee SJ, Sohn JH, et al. Anti-neuroinflammatory effects of citreohybridonol involving TLR4-MyD88-mediated inhibition of NF-small ka, CyrillicB and MAPK signaling pathways in lipopolysaccharidestimulated BV2 cells. Neurochem Int. 2016;95:55-62.

84. Lillsunde KE, Festa C, Adel H, De Marino S, Lombardi V, Tilvi S, et al. Bioactive cembrane derivatives from the Indian Ocean soft coral. Sinularia kavarattiensis. Mar Drugs. 2014;12:4045-68.

85. Choi JY, Hwang CJ, Lee HP, Kim HS, Han SB, Hong JT. Inhibitory effect of ethanol extract of Nannochloropsis oceanica on lipopolysaccharide-induced neuroinflammation, oxidative stress, amyloidogenesis and memory impairment. Oncotarget. 2017:8:45517-30.

86. Ebrahimi-Kalan A, Soleimani Rad J, Kafami L, Mohammadnejad D, Habibi Roudkenar M, Khaki AA, et al. MS14 downregulates Lipocalin2 expression in spinal cord tissue in an animal model of multiple sclerosis in female C57BL/6. Iran Biomed J. 2014;18:196-202.

87. Ahmadi A, Habibi G, Farrokhnia M. MS14, an Iranian herbal-marine compound for the treatment of multiple sclerosis. Chin J Integr Med. 2010;16:270-1.

88. Chen WF, Chakraborty C, Sung CS, Feng CW, Jean YH, Lin YY, et al. Neuroprotection by marine-derived compound, 11-dehydrosinulariolide, in an in vitro Parkinson's model: a promising candidate for the treatment of Parkinson's disease. Naunyn Schmiedebergs Arch Pharmacol. 2012;385:265-75.

89. Feng CW, Hung HC, Huang SY, Chen $\mathrm{CH}$, Chen YR, Chen CY, et al. Neuroprotective effect of the marine-derived compound 11-dehydrosinulariolide through DJ-1-related pathway in in vitro and in vivo models of Parkinson's disease. Mar Drugs. 2016;14:E187.

90. Wen $\mathrm{ZH}$, Chao $\mathrm{CH}$, Wu MH, Sheu JH. A neuroprotective sulfone of marine origin and the in vivo anti-inflammatory activity of an analogue. Eur J Med Chem. 2010;45:5998-6004. 
91. Jean YH, Chen WF, Sung CS, Duh CY, Huang SY, Lin CS, et al. Capnellene, a natural marine compound derived from soft coral, attenuates chronic constriction injury-induced neuropathic pain in rats. Br J Pharmacol. 2009;158:713-25.

92. Lin YC, Huang SY, Jean YH, Chen WF, Sung CS, Kao ES, et al. Intrathecal lemnalol, a natural marine compound obtained from Formosan soft coral, attenuates nociceptive responses and the activity of spinal glial cells in neuropathic rats. Behav Pharmacol. 2011;22:739-50.

93. Chen NF, Huang SY, Lu CH, Chen CL, Feng CW, Chen CH, et al. Flexibilide obtained from cultured soft coral has antineuroinflammatory and analgesic effects through the upregulation of spinal transforming growth factor-beta 1 in neuropathic rats. Mar Drugs. 2014;12:3792-817.

94. Lu Y, Zhao LX, Cao DL, Gao YJ. Spinal injection of docosahexaenoic acid attenuates carrageenan-induced inflammatory pain through inhibition of microglia-mediated neuroinflammation in the spinal cord. Neuroscience. 2013:241:22-31.

95. Xiao AJ, Chen W, Xu B, Liu R, Turlova E, Barszczyk A, et al. Marine compound xyloketal B reduces neonatal hypoxicischemic brain injury. Mar Drugs. 2015;13:29-47.

96. Kim JH, Lee NS, Jeong YG, Lee JH, Kim EJ, Han SY. Protective efficacy of an Ecklonia cava extract used to treat transient focal ischemia of the rat brain. Anat Cell Biol. 2012;45:103-13.

- fast, convenient online submission

- thorough peer review by experienced researchers in your field

- rapid publication on acceptance

- support for research data, including large and complex data types

- gold Open Access which fosters wider collaboration and increased citations

- maximum visibility for your research: over 100M website views per year

At BMC, research is always in progress.

Learn more biomedcentral.com/submissions 